\title{
MOTIVATION AND LIFE STYLE OF THE CZECH AMENITY MIGRANTS (CASE STUDY)
}

\author{
Michael Bartoš, Drahomíra Kušová, Jan Těšitel ${ }^{1}$
}

Received 16 June 2009; Accepted 5 August 2009

\begin{abstract}
Amenity migration is a specific type of migration which is not motivated by higher wages - it has been brought about by the desire to render more valuable natural or socio-cultural environment of the target territory, and it is often directed from metropolitan to rural areas. The group of amenity migrants from chosen areas of the Czech Republic was described and identified on basis of collected empirical data set. Results are discussed with relevant authors who currently study amenity migration abroad. It follows from the mentioned results that amenity migrants in model areas are rather university educated, economically strong and more creative. They prefer natural amenities to cultural ones, their in-migration is not related to tourism and second homes phenomenon as it was expected earlier. They use current residential potential for permanent living in the amenity-rich places.
\end{abstract}

Keywords: Amenity migration, tourism, second home, Czechia

Souhrn: Amenitní migrace je chápána jako specifický typ lidské migrace, která není motivována ekonomicky, ale snahou žít $v$ celkově hodnotnějším socio-kulturním prostředí a směřuje převážně $z$ městského prostředí do venkovské krajiny. Ve vybraných modelových územích České republiky byly na základě terénního sběru dat identifikovány a popsány skupiny amenitních migrantů. Výsledky jsou diskutovány $s$ autory zabývajícími se amenitní migrací v zahraničí. Z uvedeného průzkumu vyplývá, že amenitní migranti $v$ modelových územích jsou převážně vysokoškolsky vzdělaní, mají větší ekonomickou sílu a zároveň jsou více kreativní. Dávají přednost prírodním hodnotám území před kulturními. Jejich migrace není svázána s cestovním ruchem či "druhým bydlením", jak se předpokládalo. Dávají zároveň přednost stávajícímu bytovému fondu na venkově před výstavbou nových objektů.

Klíčová slova: amenitní migrace, cestovní ruch, druhé bydlení, Česko

\footnotetext{
1 Ing. Michael Bartoš, CSc., e-mail: michlba@usbe.cas.cz, PhDr. Drahomíra Kušová, e-mail: draku@usbe.cas.cz, Ing. Jan Těšitel, CSc., e-mail: jante@usbe.cas.cz, Faculty of Agriculture, University of South Bohemia (USB) in České Budějovice, Branišovská 31, CZ 37005 České Budějovice, Czechia and Institute of Systems Biology and Ecology, Academy of Sciences of the Czech Republic, v.v.i., Na Sádkách 7, CZ 37005 České Budějovice, Czechia
} 


\section{Introduction}

Throughout the history of the Czech lands, motivation for people to live in different environments for shorter or longer periods has changed. The region of present-day Czech Republic underwent many socio-political, economic and cultural waves influenced the amenity migration's phenomenon and created its specific forms (Bartoš et al. 2008a). The geographical scale of the Czech Republic plays significant role of the connection between the phenomena of "second home" and "amenity migration" (Bartoš et al. 2008b, c).

Amenity migration (Moss 2006) is described as an emerging global phenomenon. It is a specific type of migration which is not motivated by economic prosperity - it has been brought about by the desire to render more valuable the natural or socio-cultural environment of the target territory, and it is often directed from metropolitan to rural areas or else to historic "hearts" of cities. This phenomenon has been strongly supported by the spread and growing accessibility of mass information technologies (Glorioso 1999). As with any other kind of migration, it can lead to changes in the spatial distribution of human activities in the target territory.

Migration, in general, has been rather narrowly conceptualized as the "relatively permanent" change of address or abode driven mainly by a desire to maximize owes economic position. However, reversal of the rural-urban migration in the 1960's and 1970's brought into question the singularity or even the dominance of economic motives and raised the possibility of a wider variety of reasons including those related to quality of life (Mclntyre et al. 2006).

Special type of the migration seems to be environment-induced migration. The quality of environment represents one of the basic determinants of population migration (Drbohlav 1994). Also Carr (2005) says that environment cannot be excluded from the decision to migrate because it is always a part the knowledge of local environs and thus it always participates in the decision to migrate. On the other hand Kavanová, Stojanov (2008) state that the concept of environment-induced migration results from the theory of 'forced (involuntary) migration' that describes the potential factors that 'force' people to involuntary leaving of their habitats. It is the main reasons why these authors excluded the amenity migration from the frame of environmental migration.

However Moss (1994) distinguishes in his concept two basic forms of amenity migration. Results of research carried out by Moss (1987) from the mid-1980s show that it is possible to distinguish two key factors that cause amenity migration. The first is migration motivated by the opportunity to live in a better natural environment (natural amenities). Moss (2006) specifies that: "Environmental amenities are the valued natural physical attributes of places, including terrestrial and aquatic landscapes, distinguishing topographical features, climate, air, water and biodiversity quality and quantity". The second, migration may be aimed at specific socio-cultural aspects of the target territory (cultural amenities). This includes, for example, a specific lifestyle or local community character, tradition, religious practice, or small-scale production practices of a specific character. Such socio-cultural amenities were the main reason for emigration among "neo-ruralists" in Western Europe in the 1970s. Currently, there appears to be a group of migrants that is focused exclusively on the cultural specifics, its "genius loci". In this case, people migrate to historical towns and cultural centers.

The process of amenity migration can be described as a motion with two driving forces known as a push-pull theory: (1) "anti-urban" push factors from cities include crime, congestion, costs and low quality of environment, and (2) "pro-rural" pull factors include attraction of a better environment, a more tranquil lifestyle and/or a genuine move towards rurality "where the majority of daily needs can be met in local market towns" (Halliday and Coombes 1995). The first group of factors (anti-urban) is possible to understand as a push force for "environmental migration". The term "environmental migrants" has been suggested to denote migration due to both environmental and non-environmental factors working together (Reuveny 2005).

Recently, other approaches have been formulated to describe and explain the origins of amenity migration. One of these is based on the general principles of tourism, i.e. getting to know new places during one's free time with a gradual transition to amenity migration (Steward 2002). A second phenomenon, which can be understood as an intermediate stage, is that of people with second homes (Bičík et al. 2001). The latter approach assumes that amenity 
migrants leave the places in which they currently live spontaneously, being dissatisfied with life in the city (Glück and Magel 1992; Librová 1994, 2003). The former category is informed about the place itself and the local community, whereas members of the latter group are heading for "the unknown" and their expectations are high.

Steward (2002) describes five basic steps leading to amenity migration, with its beginning being conditioned by yet another human activity, tourism. Steward assumes that the initial impulse bringing about amenity migration could be connected with experience mediated by a form of tourism. In this sense, as regards the visitors, the necessary preconditions would be free time and financial means. This indicates that amenity migrants come from a group who are "economically strong" or, in other words, "well-off", and whose presence in the territory can positively influence regional development (Blažek 2002).

Tourists usually visit places without the intention of residing or earning a living in their destinations. Amenity migrants, however, settle in their destination, where they reside permanently, seasonally or intermittently (Glorioso and Moss 2007). Others have defined amenity migrants differently. Chipeniuk (2006) and Buckley et al. (2006), for example, consider only those who move permanently to be amenity migrants. In some areas of North America, the development of amenity migration has been described differently. What tends to happen is that people who have the intention to move to some amenity-rich place keep their eyes open for a situation that might suit them; then they check out possibilities among communities or districts praised by word of mouth or in the media; and finally, when the time is right, they simply move to their selected place, full-time (Chipeniuk 2006).

The main motivation factors and specific life style of Czech amenity migrants is the matter of this paper. Partial empirical results gained in the framework of the project "Amenity migration as an emerging form of global human migration. Its role in socio-economic development of rural areas in the Czech Republic" (2007-2010) are published in the paper. The main aim of the project consists in the evaluation of the role which amenity migration plays or could play in the regional development. To achieve this objective requires the following steps: a) Description of "amenity" migration forms; b) Analysis of the factors facilitating the origin and development of this phenomenon; c) Prediction of possible development of "amenity" migration in the Czech Republic and d) Estimation of potential impacts (positive and negative) of this type of migration on the target territory.

\section{Model areas}

Though our study generally deals with the global phenomena of amenity migration, the research itself is aimed at the rural space of the Czech Republic. The attention is paid mostly to "lagging" areas which are theoretically predisposed to become amenity migrants' targets (Moss et al. 1999, 2006; Těšitel et al. 2001; 2003; Bartoš et al. 2005; Kušová et al. 2008). The initial presumption claims that these areas display a specific comparative advantage, in this case more preserved environment, and at the same time they are characterized by parameters typical of marginal (Těšitel et al. 1999) or peripheral territories (Novotná 2004). The project has been in the form of an empirical comparative study comprising three model territories - A) Šumava Mts. and its foothills, B) Třeboňsko including the territory called Česká Kanada, and C) the territory along the borders of three regions - Plzeňský, Ústecký and Středočeský - the so called "inner periphery West" (Fig. 1).

The territories have different geographical characteristics, and partially different local economies including a different level of tourism development. They are also subject to a different level of state nature conservation. All of them are considered to be "less efficient" in the sense of their economies. The reason why the big part of all the model territories are considered to be "less efficient" is, excluding natural conditions, the heritage of post-war political development. Unfinished resettlement of some parts of the border area (due to the evacuation of German speaking inhabitants after the World War II) and empty farmhouses and smaller family houses in attractive localities facilitated considerable development of acquiring second homes. 


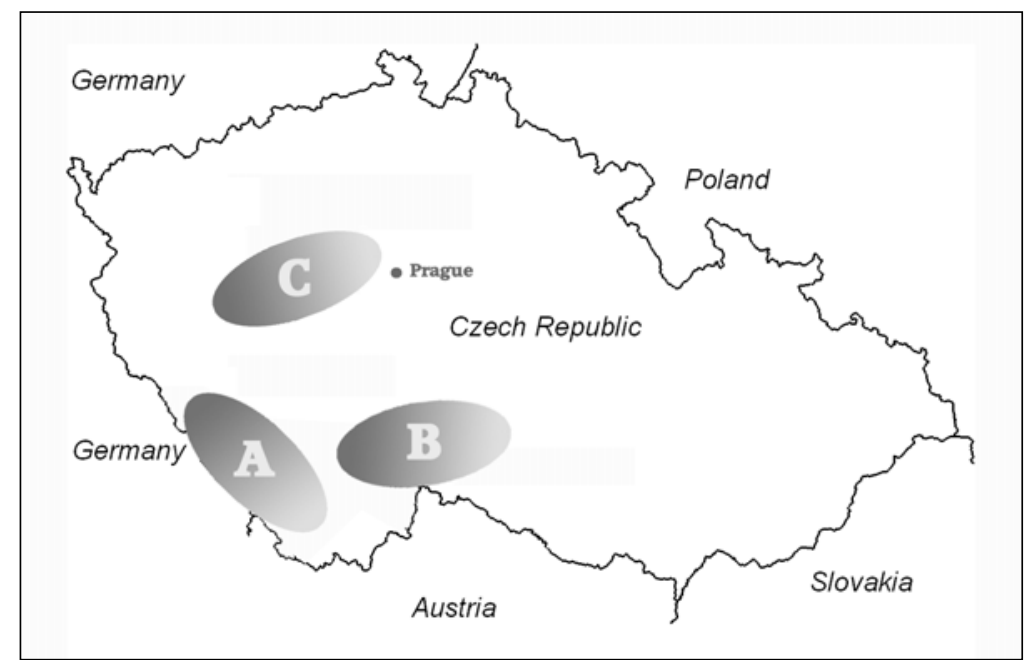

Fig 1. Model areas - A) Šumava Mts. and its foothills, B) Třeboňsko including the territory called Česká Kanada, C) the territory called "inner periphery West"

\section{1 Šumava Mts. and its foothills (A)}

The Šumava Mts. area including its foothills is a territory which, until the mid nineties of the last century, had all characteristics of a marginal area (Těšitel et al. 1999) - a low economic standard, insufficient sources of workforce, limited state subsidies to support economic development, and a decrease of agricultural production intensity. The territory could be an example of historical "outer periphery" of the Czech Republic (Novotná 2005). Since the 1990s, owing to natural attractiveness of the area (Fig. 2), tourism has become the main, very fast growing economic activity in the area. Another factor which significantly influences the development in the area is the existence of the Sumava National Park (declared in 1991) and the Sumava Protected Landscape (1963). However, the nature protection plays an ambivalent role. On one hand the National Park and the Protected Landscape Area are perceived by the visitors as a certificate of environmental quality, on the other hand their existence represents a limiting factor for some economic activities including the ban on buildings construction outside the existing settlements. For studying the phenomenon of amenity migration it is also important that the territory is located along the open state border with Germany and Austria. These factors caused that both Czech and foreign amenity migrants "discovered" this area as early as in the 1990s. It seems important for foreign migrants that they find themselves in the vicinity of cultural and economic centers in the Šumava Mts. foothills.

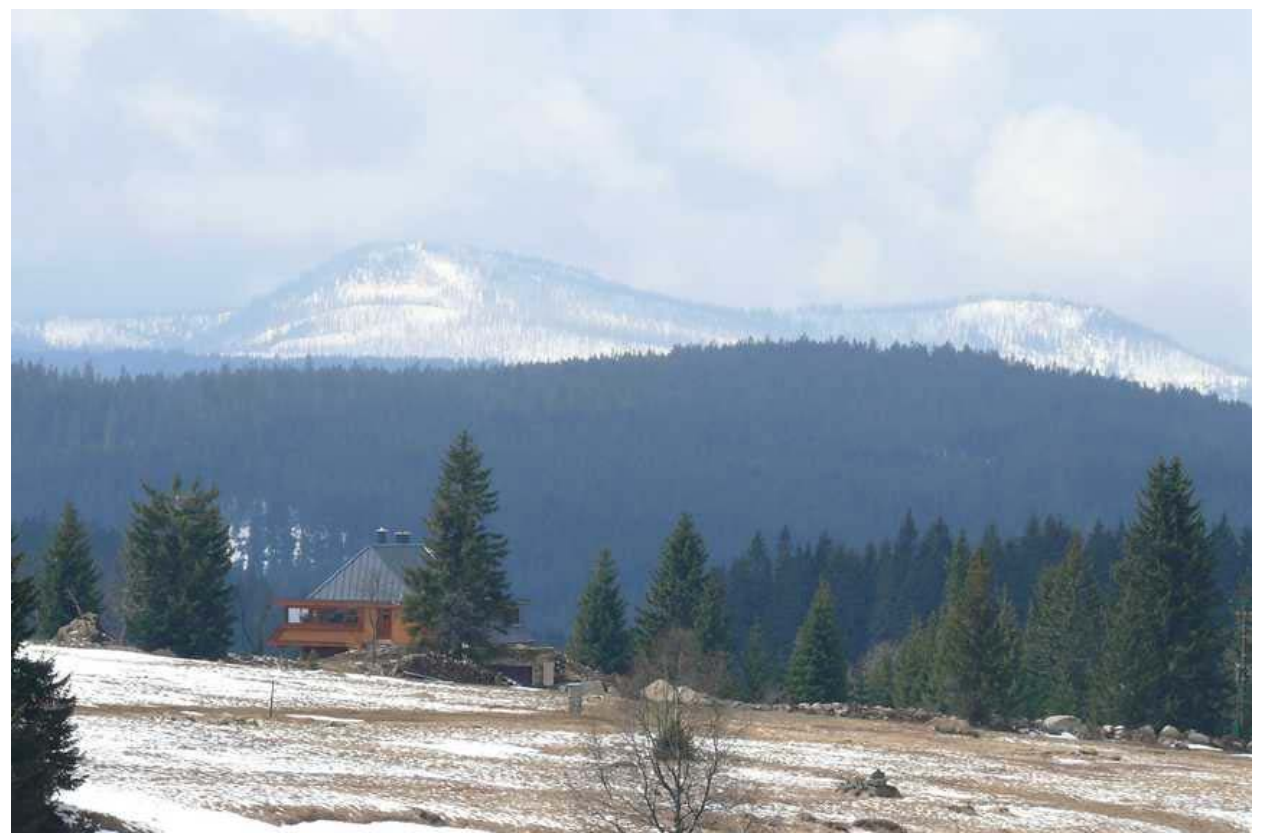

Fig 2. Natural attractiveness of Šumava Mts. 


\subsection{Třeboňsko and Česká Kanada (B)}

This model area is situated in the south of Bohemia in the district of Jindrichův Hradec and spreads along the historical border with Moravia. It can be divided into two independent parts: the Třeboň basin and the highlands of Česká Kanada. Despite that they have one thing in common - like in the Šumava Mts., their development was influenced by their existence near the state border ("iron curtain"), which made it impossible to tend the land in the sense of common land-use but contributed to the preservation of natural attributes and values. Even nowadays the territory displays the attributes of "outer periphery" of the Czech Republic (Novotná, 2004). In 1979 the Třeboňsko area acquired the status of a protected landscape.

During the last sixteen years the access to the whole border areas of Třeboňsko and Česká Kanada has been unlimited. Considering the socio-economic situation, the area is thinly populated with the prevalence of rural social structure. The main attractor seems to be its rolling land relief with a picturesque mosaic of ponds, fields, meadows and pastures, and large forests (Fig. 3). The landscape allows for broad range of varied leisure activities. The interest of amenity migrants in this territory is not as strong as in the Šumava Mts. However, current orientation surveys confirmed the existence of amenity migration phenomenon in the area of Třeboňsko.

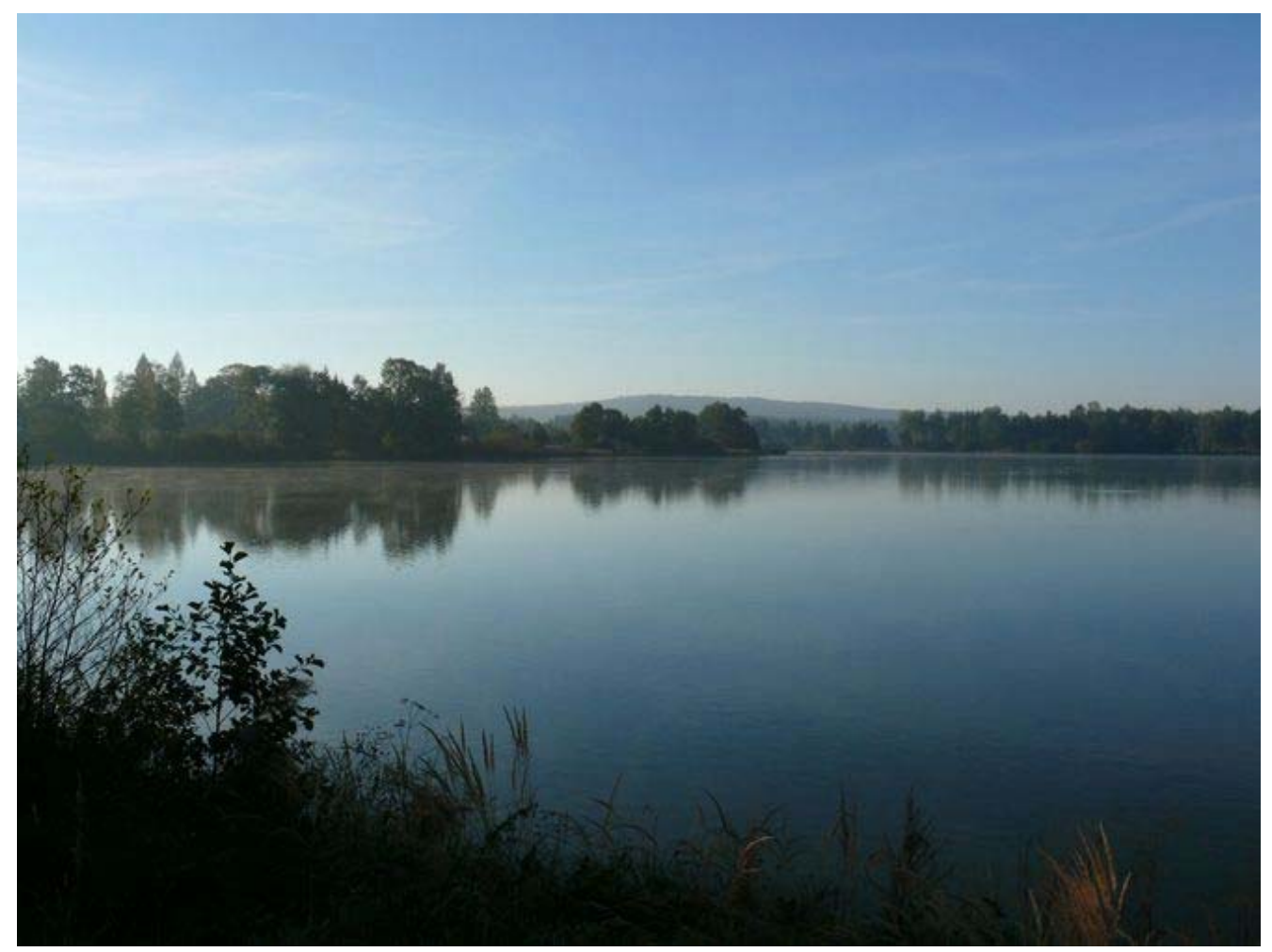

Fig 3. The rolling land relief with a mosaic of ponds in Třeboňsko and Česká Kanada area

\subsection{Territory along the border of three regions - Plzeňský, Ústecký and Středočeský, so called "inner periphery West" (C)}

The area along the border of three regions - Plzeňský, Ústecký and Středočeský - is an example of historic "inner periphery" of the Czech Republic (Fig.4). It can be also described as marginal though the distance from economic and political centers is smaller than that of the above-mentioned territories (it is situated only $40 \mathrm{~km}$ north from Plzeň and $60 \mathrm{~km}$ from Prague). It does not spread along the state border nor includes the former area of the "iron curtain". Despite this fact it displays the characteristics typical of marginal territories, namely low economic effectiveness, permanent decline of population, less effective agricultural production, poor infrastructure including the services necessary for tourism development. Due to the lack of job opportunities, local inhabitants must search for work in distant places. Even in the history 
the territory was not very busy and important - it had always been far from the main urban centers and situated off the main roads.

The chosen area is a typical landscape of agriculture and forestry along the Berounka river (Novotná, 2005). The north of the territory partly includes the large-area Krrivoklátsko Protected Landscape (declared in 1978). The natural as well as cultural and historical values of the region represent a potential usable for tourism development or as an attractor for "amenity" migrants. In the nearness to the towns of Prague and Plzeň is emerging the phenomenon of residential places with commuting to the towns - peri-urban development (Perlik 2001).

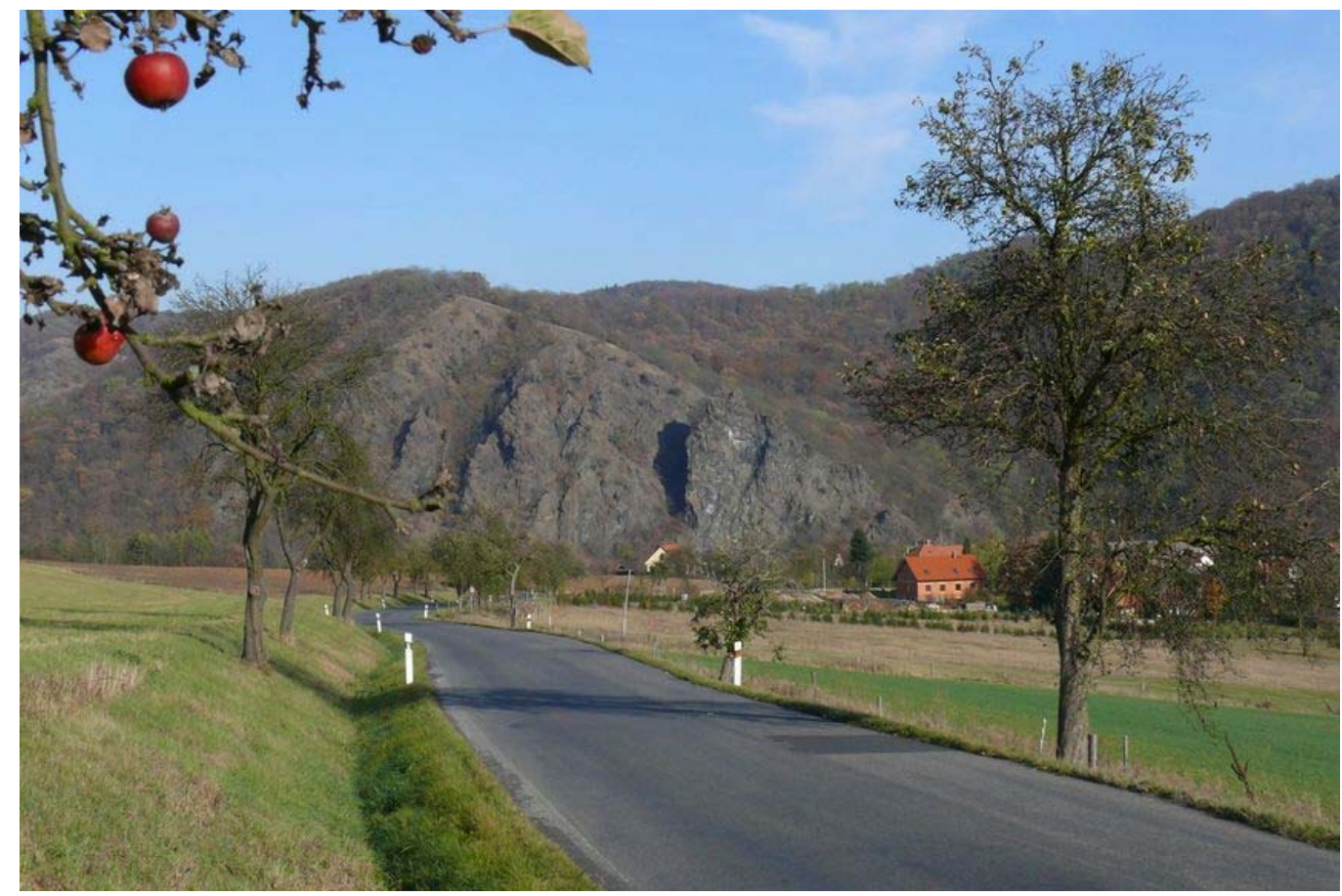

Fig 4. Typical landscape in the area of the "inner periphery"

\section{Methods used for describing amenity migrants}

The complexity of the problem and the necessity of dealing with local knowledge led to the decision to use a combination of quantitative and qualitative research methods (Hendl 2005). Semi-standardized interviews with key representatives of local communities (mainly with mayors) were used to identify particular amenity migrants. Thanks to the interviews with key representatives, about 100 amenity migrants were identified. The approach of "maximal variety" and the approach of personal recommendation - "snow ball" (Patton 2001) were used in the process of identification the respondents.

During late summer and fall 2008, the questionnaire survey aimed to reveal the motivation for migration, life style and life time strategies of amenity migrants, identification of amenity migrant types, their behavioral patterns and their expected demands concerning the locality was realized. Amenity migrants, adult people older than fifteen, living in the model areas formed the basic set. The sample was derived from it by use of pilot field research data. The number of addressed amenity migrants has been 74 up to the present time. The most respondents $(61 \%)$ were from the model area of the Šumava Mts. and its foothills. From the second model area Třeboňsko basin and Česká Kanada mountain range we were able to identify and get data from 18 respondents $(24 \%)$. From inner periphery modeled area we were able to get the smallest amount of respondents, they were only $11(15 \%)$. Based on the very data spatial distribution, we can already say that the area of Šumava Mts. is more attractive for amenity migrants (Moss et al. 1999) than inner periphery. Area of inner periphery has well preserved nature habitats and has great recreational potential. It has been used mostly for short-term recreation (second homes) and it's very little inhabited by amenity migrants. This is mostly caused by relative proximity of capital city and by progressing urbanization. 


\section{Results and discussion}

Selected results describing research sample of amenity migrants in three model areas representing the situation in the Czech Republic are mentioned in this part of article. From gender point of view prevailed female respondents $(63 \%)$. Other selected characteristics of amenity migrants are mentioned in Table 1 . Group of people aged 30 to 39 was mainly present $(43 \%)$, and in terms of education, university students prevailed $(47 \%)$. High school education had $43 \%$ of respondents while other categories were almost not present at all. From this point of view, we can deduct that amenity migration is preferred by educated people who are willing to change their lifestyle, are wealthier and have certain level of creativity. Distribution of respondents according to their jobs, confirms this trend: from the total number of amenity migrants is mostly one third $(27 \%)$ active in their own business. One fifth of respondents were women for whom the main reason for amenity migration was need to raise their children in better natural environment.

From the length of stay point of view it was shown, that most of amenity migrants live in the area for the whole year (92\%), the rest stays irregularly or during certain seasons respectively. Also Chipeniuk (2006) considers only those who move permanently as amenity migrants. The line dividing amenity migrants and seasonal second homes recreants can be in some cases very fuzzy. One fifth of amenity migrants stated, that they still have their original homes and that's why they fit in the definition of second homes owners by Bičík et al. (2001) or seasonal migrants (Glorioso 1999).

\begin{tabular}{|c|c|c|}
\hline $\begin{array}{l}\text { Characteristics } \\
\text { (variable) }\end{array}$ & Variable value & $\begin{array}{c}\text { Percentage } \\
(\%)\end{array}$ \\
\hline \multirow{5}{*}{ Age } & $20-29$ & 11 \\
\hline & $30-39$ & 43 \\
\hline & $40-49$ & 18 \\
\hline & $50-59$ & 18 \\
\hline & 60 and more & 10 \\
\hline \multirow[t]{4}{*}{ Education } & Elementary school & 1 \\
\hline & Training institution & 10 \\
\hline & High school & 43 \\
\hline & University & 46 \\
\hline \multirow[t]{5}{*}{ Source of income } & Retirees & 11 \\
\hline & Self employed & 27 \\
\hline & Employed & 32 \\
\hline & Maternity & 22 \\
\hline & Others/combination & 8 \\
\hline \multirow[t]{2}{*}{ Length of stay } & Permanently & 92 \\
\hline & Seasonally, intermittently & 8 \\
\hline \multirow[t]{3}{*}{ Attitude towards life style } & Rural lifestyle & 36 \\
\hline & Urban/town lifestyle & 10 \\
\hline & Unidentifiable & 54 \\
\hline \multirow[t]{2}{*}{ Living standard satisfaction } & Yes & 90 \\
\hline & No & 10 \\
\hline \multirow[t]{2}{*}{ Willingness to move out } & Yes & 15 \\
\hline & No & 85 \\
\hline
\end{tabular}

Tab 1. Selected characteristics of amenity migrants; source: own field research (2008); $n=74$

From Table 1 we can see that $85 \%$ of respondents are not interested in moving away and also majority of them (90\%), are content with their living standards. House living standards in such cases are similar to country side living standard in the Czech Republic. For example 90\% surveyed families own car and cell phone, $77 \%$ own personal computer and $68 \%$ is connected to Internet. Only some of them reject TV as part of their life style philosophy. Nevertheless from 
characteristics mentioned above, we can see that Czech amenity migrants are part of the "economically strong" part of society (Blažek 2002). In our earlier studies (Bartoš et al. 2008b) we described new types of amenity migrants they have emerged after 1990. They are rich amenity migrants from different places in the Czech Republic. Most of them are young and skilled people (in comparison with average Czech citizens).

More that four fifths of respondents own a property in the area. From Figs. 5 and 6 we can see that $65 \%$ of respondents bought the property, $11 \%$ inherited it and only $9 \%$ built it. One half of respondents live at farm house, more than one third lives in country side house (villa). Only $7 \%$ of respondents stated, that they live in apartments or block of flats respectively. All other amenity migrants live in places like mobile homes or former utility buildings as church rectory, school, village poorhouse, custom-house, etc. Amenity migrants in the Czech Republic live mostly in houses which they reconstruct by themselves from older properties. Thus amenity migration has little effect on local settlement development (Bartoš et al. 2007).

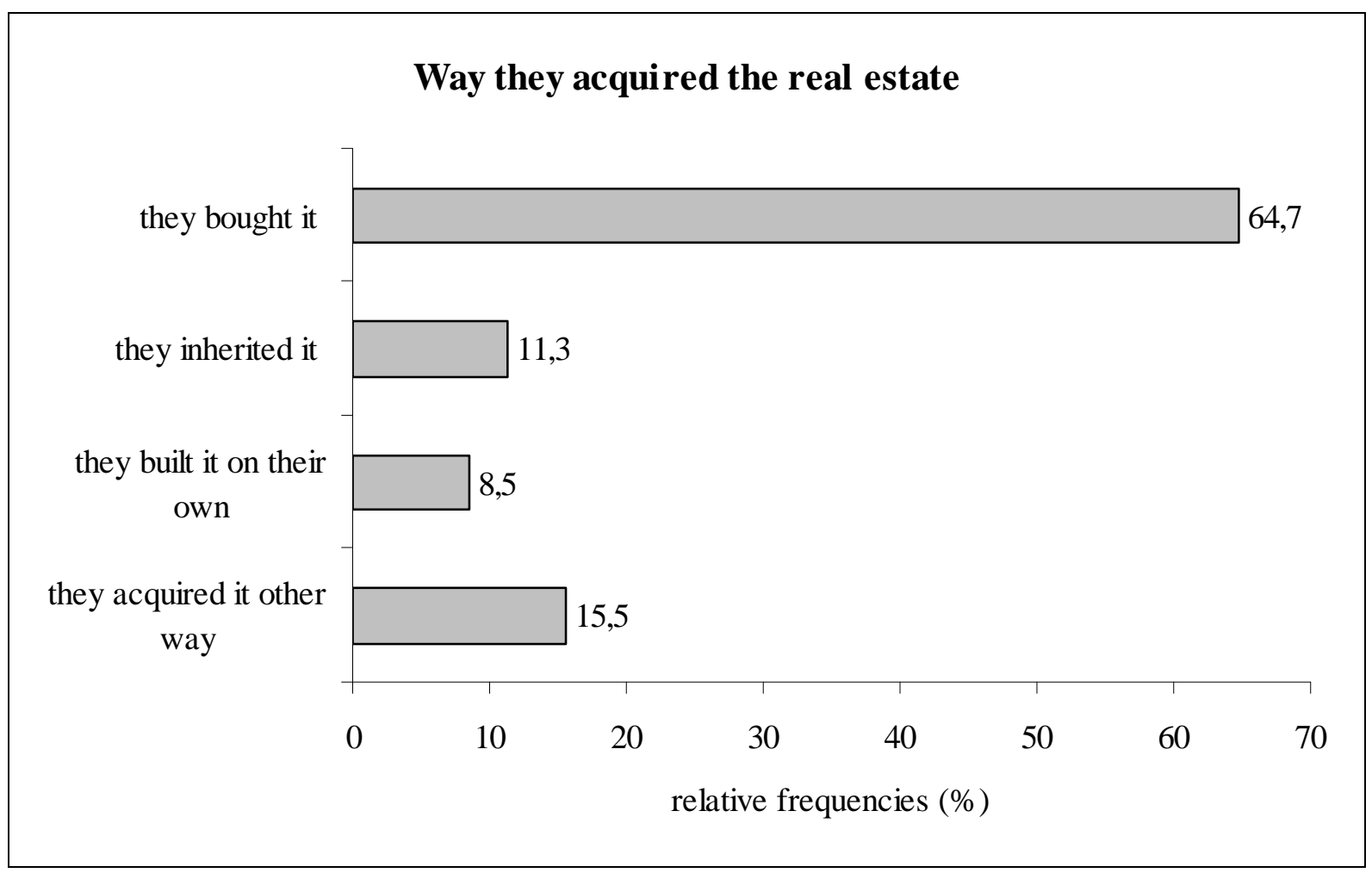

Fig 5. The real estate acquisition. Source: own field research (2008); $n=74$

Amenity migrants strive to change the place in which they live due to internal, psychological factors (Novotná, Kopp, 2008); it is an act of their personal indulgence. Indulgence, in this case, means being aware of the values of life in a natural environment, that is only moderately polluted and far from bustling civilization, being fascinated with rural life, or the desire to live in a culturally different community. From the lifestyle point of view, we can say, that typically rural life style was adopted by $36 \%$ of respondents and urban by $10 \%$ of them. Most of them specified their life style as a mixture of urban and rural life style (54\%), see Table 1 . One half of amenity migrants stated, that they didn't live their childhood at rural places, neither they had experienced rural life style or manual work associated with life at such rural places. They are not connected with a particular place personally and the contact with host community is different - they don't need any help from local people, they are in a different social class (Bartoš et al. 2008c). However two fifths of respondents are well established in local social structure (volunteer firemen, maternity centre, etc.) and little less than one fifth are also involved in local self-governance. Their participation in municipal decisions demonstrates particular level of amenity migrant's integration. 


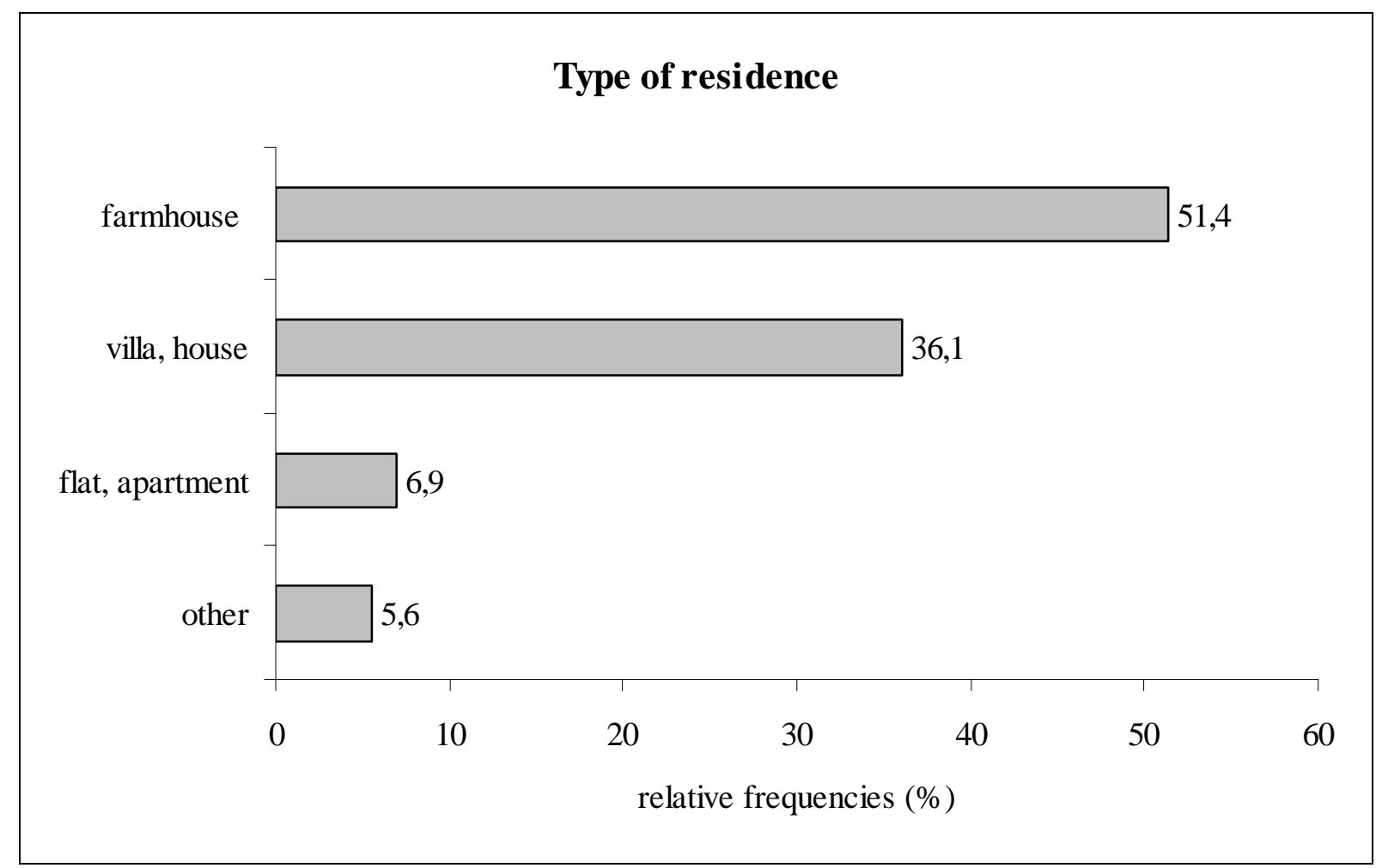

Fig 6. The type of amenity migrant's residence. Source: own field research (2008); $n=74$

It could be also mentioned that the hypothesis of continual change of tourists into amenity migrants did not prove correct. Steward (2002) assumes that the initial impulse bringing about amenity migration could be connected with experience mediated by a form of tourism. From Fig 7 , it is possible to see that only $23 \%$ of tourist people discovered their future place of interest during their recreational stay. Other respondents discovered their place in different way: $23 \%$ found their way back to their roots of origin, one fifth was searching for a place at the country side through various reality agents, internet, ads or other means. The same ratio of respondents chooses their new location according to their friend's recommendations. The rest of respondents discovered the place on business trip or they followed their partner. It is clear from Fig 8 that more than half of respondents $(52 \%)$ didn't know their amenity place before they moved in. They have never used the surrounding area of their amenity place for any recreational activities neither they have wanted this place to become attractive for tourist in any commercial way.

From the point of view of push-pull theory (Halliday and Coombes 1995), it was discovered that main reason for moving in (pull factors) into new amenity-rich place were the following reasons: $33 \%$ personal positive attitude toward nature and landscape, $21 \%$ bad environment at former place of residence. The rest stated that it was part of their housing or family problems solution (see Fig 9). Those findings correspond with analysis of this question: "What did you dislike at the place of your former residence?" It was revealed that a bad environment (noise, smog, dust, dirt, etc.) was the main reason for $35 \%$ of respondents and all negative features of urban life style (stress, overcrowding, speed, busy life, traffic jams and crime) for the next $31 \%$. From this we can deduct, that two thirds of respondents feel that they were forced from the cities by environmental push factors. The same dissatisfaction with life in the city states Librová (1994, 2003). One quarter of respondents became amenity migrants when they tried to solve their problems (little living space, living in concrete block houses, life in block of flats, expensive housing). This fact shows us that economical, environmental and amenity migration overlaps (Reuveny 2005). 


\section{Way they discovered the place}

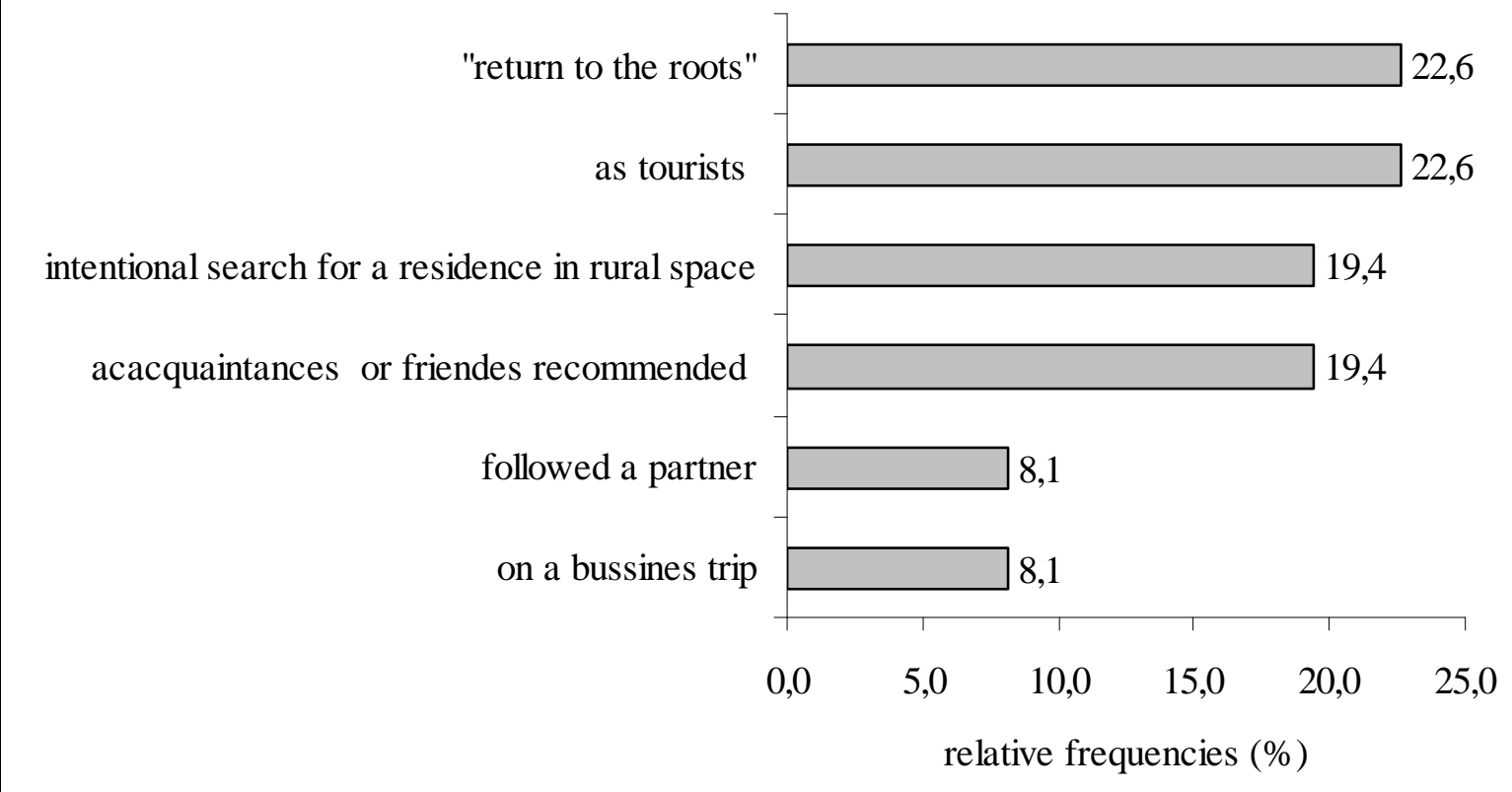

Fig 7. Discovery of the amenity-rich place. Source: own field research (2008); $n=74$

\section{Attitude to the present place of living}

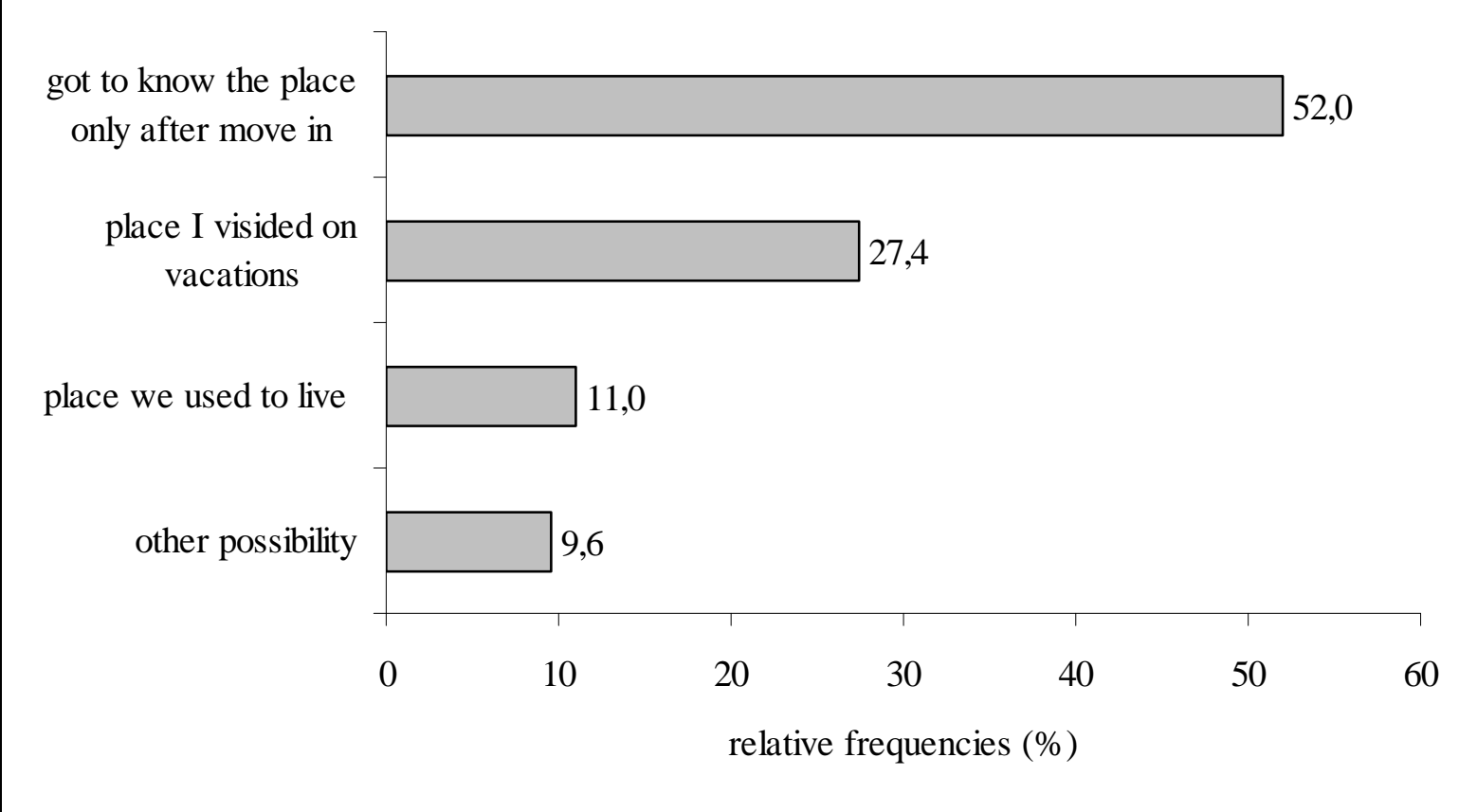

Fig 8. Attitude of amenity-rich place. Source: own field research (2008); $n=74$ 


\section{The reasons for move in}

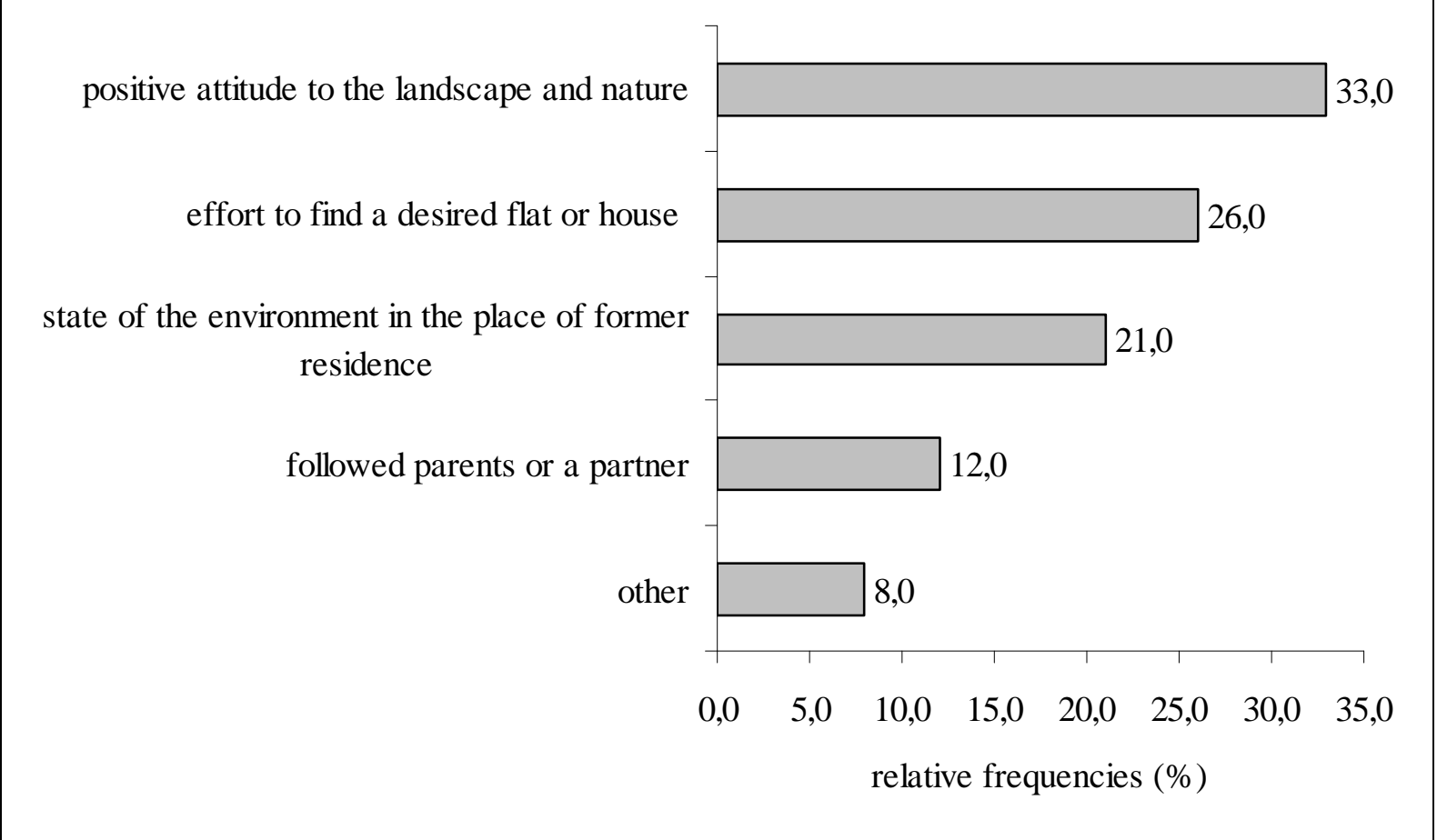

Fig 9. The reasons for move in. Source: own field research (2008); $n=74$

What "amenity parameters" are being perceived by respondents in new environment? Fig 10 shows that two thirds of respondents understand amenities as nature, landscape, healthy environment and quiet places (environmental reasons), $10 \%$ is seeing amenities as a possibility to own a garden or their own housing and for $6 \%$ amenities mean a possibility to be left alone on their own with a degree of privacy. Those migrants can be seen as a part of so called natural amenities migrants (Moss 2006). Friends and neighborhood relationships were sought after only by $12 \%$ of respondents. Those amenity migrants are part of cultural amenities migrants group (Moss 2006). They understand life in countryside not just from natural point of view. Analysis of a question, where respondents were giving their opinion how they recognize amenity-rich place, corresponds with results mentioned above. The selection of place itself was mainly influenced by pristine natural environment, quality of environment, by structure of surrounding landscape, by genius loci, by relief of landscape, by its remoteness of the area or by existence of a nearby protected area. The least decisive factor was the quality of social environment. Prevailing trend of amenity migrants can point to their difficult adaptation in local social structure in the future.

What do the respondents dislike at their new places? One quarter mentions bad infrastructure and services. The same amount of respondents is not pleased with the transport availability. Among less mentioned negative attributes are: low employment possibility, exhausting countryside jobs and difficulties arising during winter season. It is important to stress out that $14 \%$ of respondents do not see any negatives at all at their amenity-rich places ("all is o.k." was their answer). 


\section{"Parameters of amenity" as perceived by the respondents}

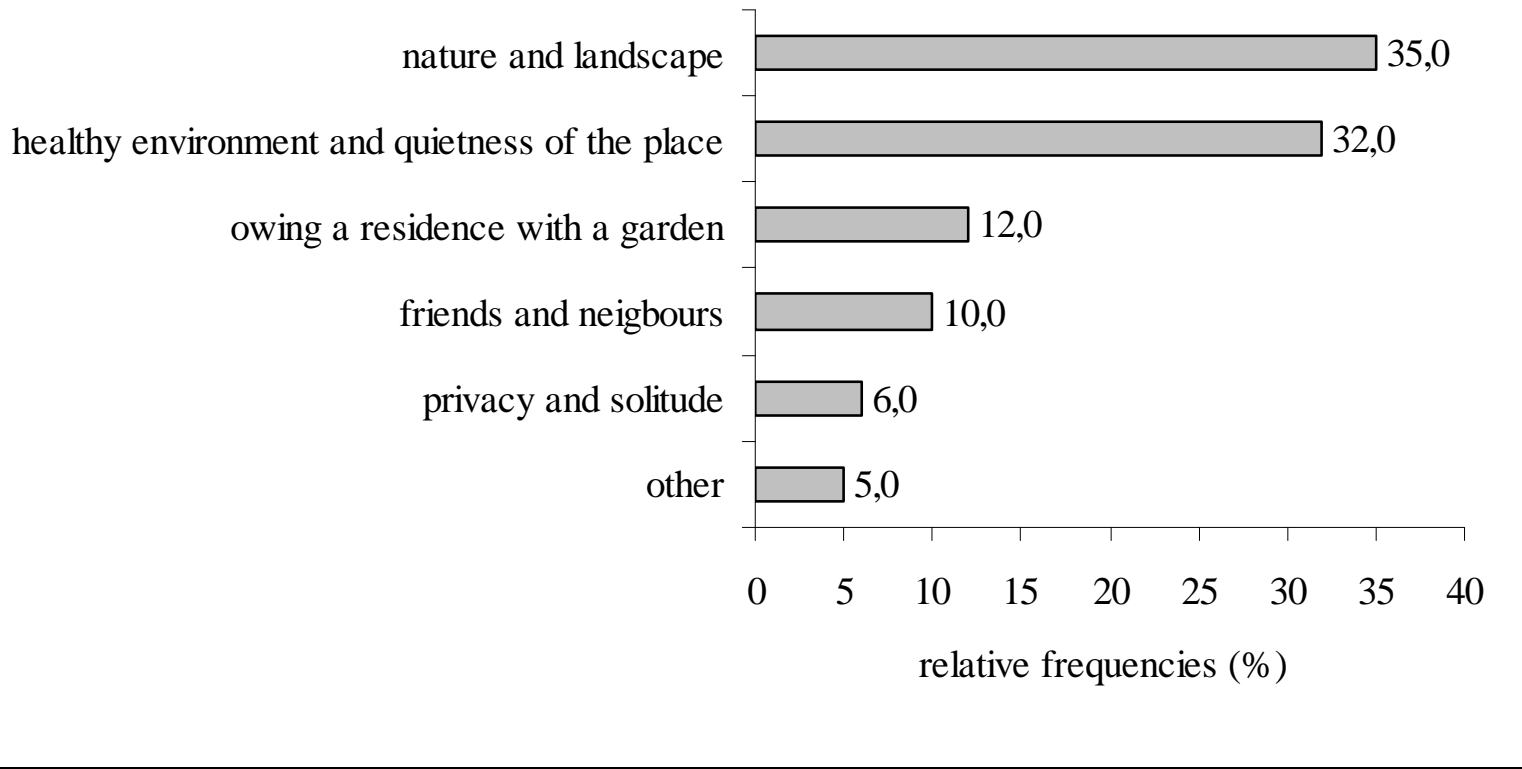

Fig 10. Parameters of amenity. Source: own field research (2008); $n=74$

\section{Conclusion}

The philosopher and sociologist Bauman (1995) says: "Nowadays all of us are in permanent motion". However, permanent traveling carries both advantages and negative impacts on the environment but also in the sphere of social relationships. Amenity migration can be an alternative to frequent traveling seeking for a better environment, at least for a certain group of people. Amenity migration is an important indicator of a reading of "post-tourism" and leads to the hybridization among residential, economic and entertainment functions (Bourdeau, 2008).

The increasing role of amenity migration in the local development of rural areas in the Czech Republic is expected. In this context, rural and mountain regions or towns with strong "genius loci" have a potential competitive advantage as desirable destinations since the character of their social, cultural, natural and also economic attributes may be especially appropriate to cultural commodification and the re-valorization of place (Kušová et al 2008; Perlik 2008). Under certain conditions amenity migration can become one of the societal driving forces determining the socio-economic development of a given region (Bourdeau, 2008).

There are two possible ways "amenity migrants" can influence the quality of life of the local population. Positive impacts would consist of a slower rate of rural areas depopulation together with maintaining certain services, an increase in the number of both temporary and permanent jobs, and the emergence of new ways of earning a living in rural areas. "Amenity migrants" can even provide new knowledge about information technologies and ways how to use it, namely in regards to the flow of subsidies into the region.

On the other hand, amenity migrants could negatively impact the lifestyle of the local population, which is generally more rooted in traditions and has evolved over centuries. A different rhythm of life, as well as different views of natural regularities, could lead to changes in the traditional country life and endanger the specific cultural potential of rural areas (Bartoš and Kušová 2005).

This case study was aimed to describe and explain the origins of amenity migration in the Czech Republic. The first results suggest that amenity migrants are rather university educated, economically strong and more creative. They prefer natural amenities than cultural amenities, their in-migration is not so closely connected with tourism and second homes phenomena as it was expected earlier (Bartoš et al. 2008b). They use current residential potential for permanent living in the amenity-rich places. New residential centers are not more being built in open and 
untouched landscape (Fig. 11, 12). Their adaptation in local communities in the future is the open question.

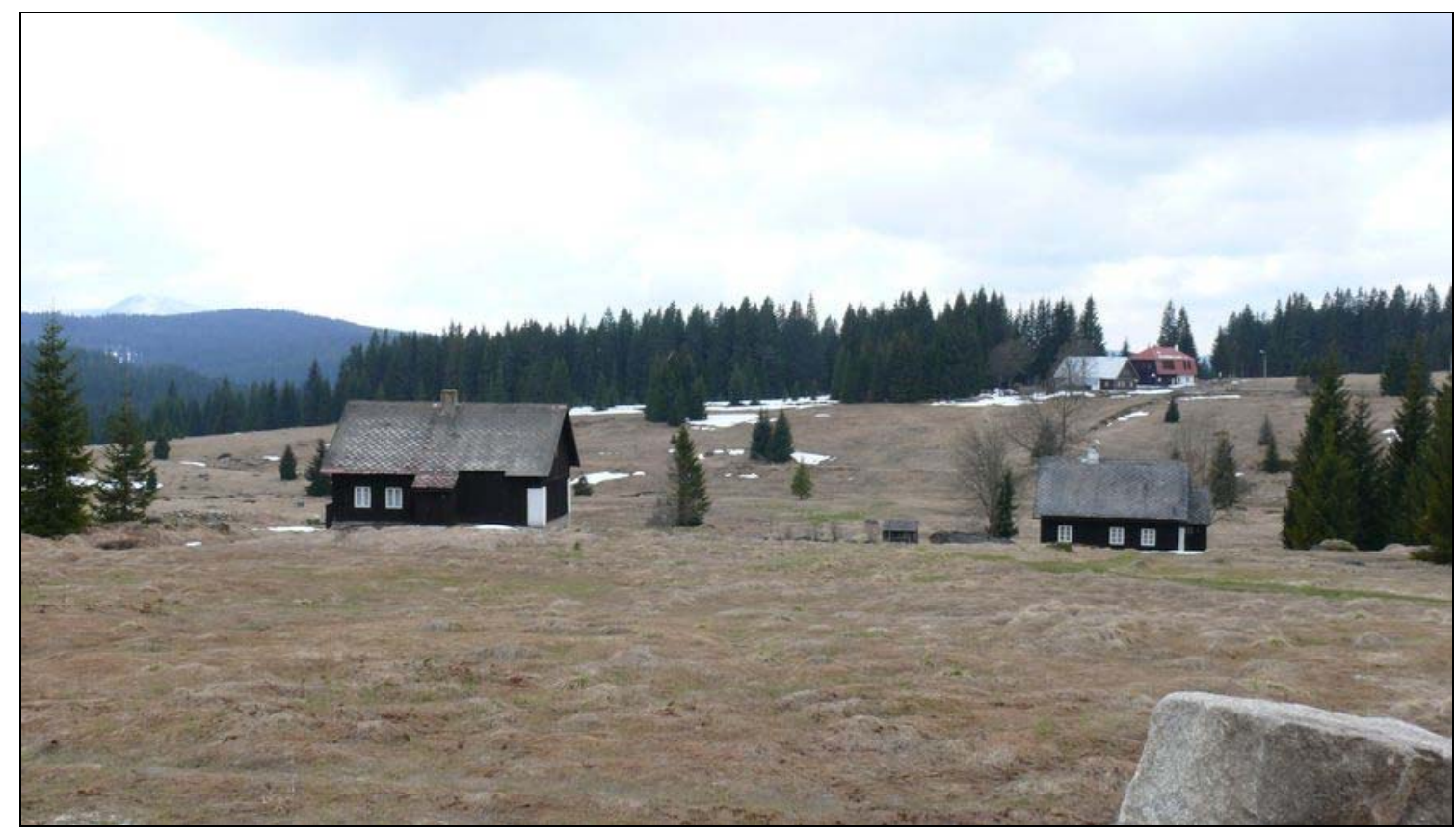

Fig 11. Amenity migrants in the Czech Republic use mostly original housing potential

\section{Acknowledgements}

This study was elaborated in the framework of the research project of the Czech Science Foundation No. 403/07/0714 "Amenity migration as an emerging form of global human migration. Its role in socio-economic development of rural areas in the Czech Republic".

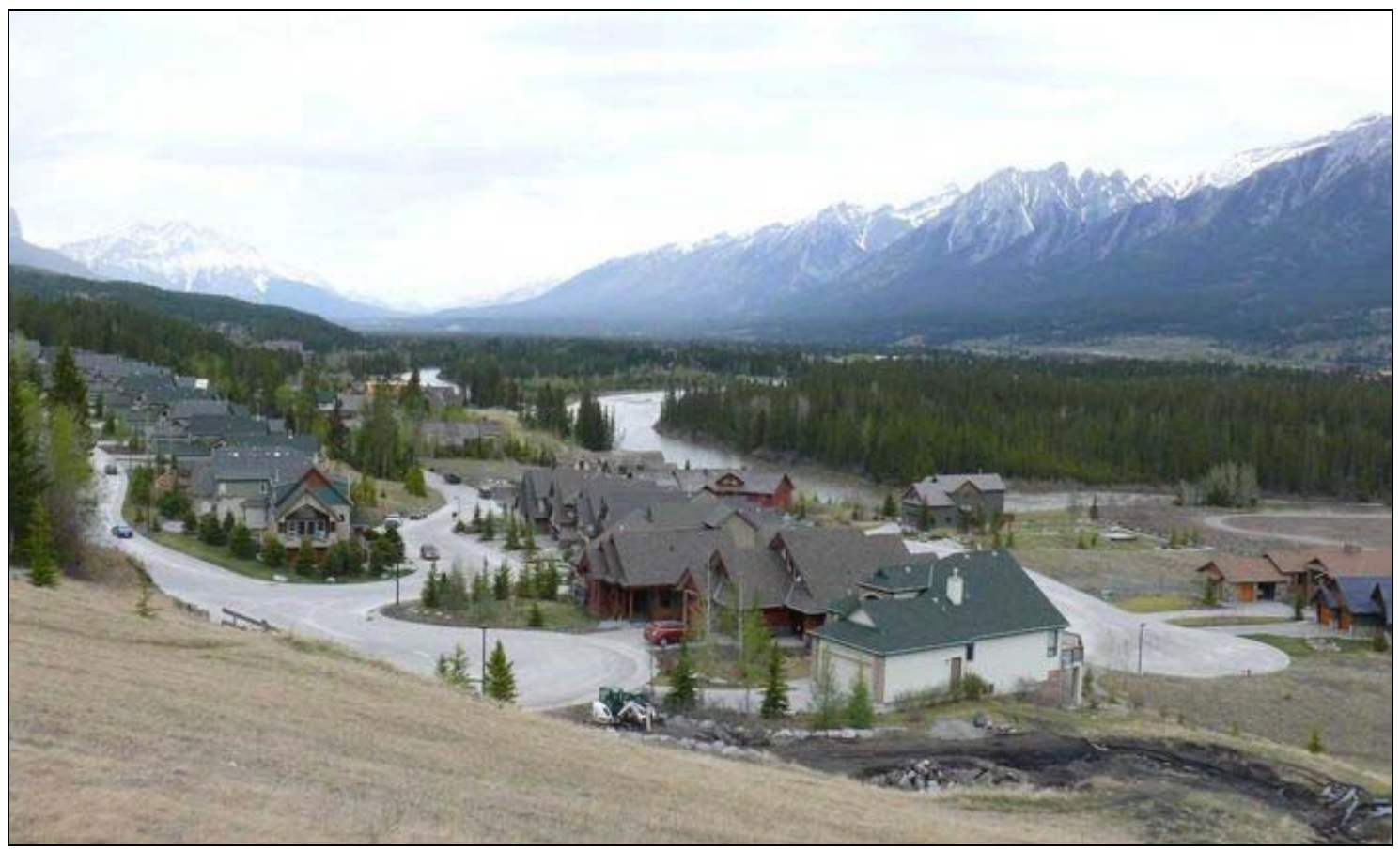

Fig 12. For North American amenity migrants is typical to live in new constructed and concentrated housing centers 
[1] BAUMAN, Z. (1995). Úvahy o postmoderní době. Praha: SLON

[2] BARTOŠ, M. \& KUŠOVÁ, D. (2005). Amenitní migrace jako nová forma specifické globální migrace a její vliv na kvalitu života. Životné prostredie 39(6), 315-318.

[3] BARTOŠ, M., KUŠOVÁ, D. \& TĚŠITEL, J. (2005). Amenity migration and tourism. In M. Hasman \& E. Šittler (eds), Sustainable development and Tourism (pp. 17-22). Faculty of Agriculture, Department of Travel Trade, Tábor.

[4] BARTOŠ, M., KUŠOVÁ, D. \& TĚŠITEL, J. (2007). Amenity migration - driving force for rural development? Agricultural economics and rural development 4(3-4), 57-69.

[5] BARTOŠ, M., KUŠOVÁ, D. \& TĚŠITEL, J. (2008a). Amenity migration as an example of the environmental migration. In R. Stojanov \& J. Novosak (eds), Migration and Development (58-75). Cambridge scholars Publishing.

[6] BARTOŠ, M., KUŠOVÁ, D., MOSS, L.A.G. \& TĚŠITEL, J. (2008b). Amenity migration in Czech Republic - place-specific character. In L.A.G. Moss, R.S. Glorioso, A. Krause (eds), Understanding and managing Amenity-led migration in mountain regions (pp. 54-64). Banf.

[7] BARTOŠ, M., KUŠOVÁ, D., TĚŠITEL, J., KOPP, J. \& NOVOTNÁ, M. (2008c). Amenity migration in the context of landscape-ecology research. Journal of Landscape Ecology 1(2), 5-21.

[8] BIČíK, I., VÁGNER, J. \& FIALOVÁ, D., (2001). Druhé bydlení v Česku. Praha: Charles University.

[9] BLAŽEK, J. \& UHLÍŘ, D. (2002). Teorie regionálního rozvoje - nástin, kritika, klasifikace. Praha: Karolinum.

[10] BOURDEAU, F. (2008). Amenity migration and post-tourism: A geo-cultural approach to the Alpine case. In L.A.G. Moss, R.S. Glorioso, A. Krause (eds), Understanding and managing Amenity-led migration in mountain regions (pp. 25-32). Banff.

[11] BUCKLEY, R., SANDER, OLLENBURG, C. \& WARNKEN, J. (2006): Green change: Inland amenity migration in Australia. In L.A.G. Moss (ed), The amenity migrants: Seeking and sustaining mountains and their cultures (pp. 278 - 294). Wallingford ans Cambridge: CABI Publishing.

[12] CARR, E.R. (2005). Placing the environment in migration: environment, economy, and power in Ghana's central region. Environment and Planning, 34(5), 925-946.

[13] CHIPENIUK, R. (2006). Planning for amenity migration in communities of the British Columbia hinterland. In L.A.G. Moss (ed.), The amenity migrants: Seeking and sustaining mountains and their cultures (pp. 163-174). Wallingford ans Cambridge: CABI Publishing.CABI Publishing.

[14] DRBOHLAV, D. (1994). Hlavní důvody a důsledky mezinárodní migrace obyvatelstva. Geografie 99(3), 151-162.

[15] GLORIOSO, R.S. (1999). Amenity migration in the Šumava bioregion, Czech Republic: Implications for ecological integrity. In P.M. Gode, M.F. Price and F.M. Zimmermann (eds.), Tourism and development in mountain regions (275-295). Oxon: CABI Publishing, CAB International.

[16] GLORIOSO R.S. \& MOSS L.A.G. (2007). Amenity migration to mountain regions: Current knowledge and strategic construct for sustainable management. Spokane: International Amenity Migration Centre. (Working paper 2007/01).

[17] GLÜCK, A. \& MAGEL, H. (1992). Das Land hat Zukunft. München: J. Jehle Verlag.

[18] HALLIDAY, J. \& COOMBES, M. (1995). In search of counter-urbanisation: some evidence from Devon on the relationship between patterns of migration and motivation. Journal of Rural Studies 11, 433-446. 
[19] HENDL, J. (2005). Kvalitativní výzkum. Základní metody a aplikace. Praha: Portál.

[20] KAVANOVÁ, K. \& STOJANOV, R. (2008). The environmental migration in Chernobyl disaster area / the case study of Belarus. In: R. Stojanov and J. Novosak (eds): Migration and Development (92-116). Cambridge scholars Publishing.

[21] KUŠOVÁ, D., TĚŠITEL, J., MATĚJKA, K. \& BARTOŠ, M. (2008). Biosphere reserves - an attempt to form sustainable landscapes (A case study of three biosphere reserves in the Czech Republic). Landscape and Urban Planning, 84(1), 38-51.

[22] LIBROVÁ, H. (1994). Pestří a zelení - kapitoly o dobrovolné skromnosti. Brno: Veronica.

[23] LIBROVÁ, H. (2003). Vlažní a váhaví. Brno: Doplněk.

[24] MCINTYRE, N., WILLIAMS, D. \& MC.HUGH, K. (2006). Multiple dwelling and tourism. Wallingford: CABI Publishing, CAB International.

[25] MOSS L.A.G. (1987). Santa Fe, New Mexico, Post-industrial amenity-based economy: Myth or model? Edmonton and Santa Fe: Alberta Ministry of Economic and Trade \& International Cultural Resources Institute.

[26] MOSS L.A.G. (2006). The Amenity Migration - seeking and sustaining Mountains and their culture. Oxfordshie/Cambridge: CABI Publishing.

[27] MOSS L.A.G. (1994). Beyond Tourism: The Amenity Migrants. In M. Mannerma, S. Inayatullah, R. Slaughter (eds.), Coherence and Chaos in our Uncommon Futures, Visions, Means, Actions. (pp. 121-128). Turku: School of Economics.

[28] MOSS, L.A.G., TĚŠITEL, J., ZEMEK, F., BARTOŠ, M., KUŠOVÁ, D. \& HEŘMAN, M. (1999). Tourism in bioregional context: Approaching ecosystemic practice in Šumava, Czech Republic. In P.M. Gode, M.F. Price and F.M. Zimmermann (eds.), Tourism and development in mountain regions (pp. 85-113). Oxon: CABI Publishing, CAB International.

[29] NOVOTNÁ, M. (2004). Metody GIS a jejich aplikace při výzkumu druhého bydlení. In J. Vágner, D. Fialová (eds.), Regionální diferenciace druhého bydlení v Česku (pp. 201-208). Praha: Charles University.

[30] NOVOTNÁ, M. (2005). Hodnocení geografického potenciálu pro cestovní ruch. In Geography, tourism and recreation (pp. 15-26). Olomouc: Palacký University.

[31] NOVOTNÁ, M. \& KOPP, J. (2008). Amenity migration into rural areas. In Countryside - Our world (pp. 442-455). Praha: Czech University of Agriculture.

[32] PATTON, M.Q. (2001). Qualitative research and evolution methods (3rd ed.). London: Sage.

[33] PERLIK, M. (2001). Alpenstädte - zwischen Metropolisation und neuer Eigenständigkeit. Geographica Bernensia. Bern: Geographisches Institut der Universität Bern.

[34] PERLIK, M. (2008). Differentiated regional development in mountain areas resulting from global change: theorethical and empirical implications for understanding amenity-seeking behavior. In L.A.G. Moss, R.S. Glorioso, A. Krause (eds), Understanding and managing Amenity-led migration in mountain regions (pp. 75-83). Banff.

[35] REUVENY, R. (2005, June 21-23). Environmental Change, Migration and Conflict: Theoretical Analysis and Empirical Explorations. Paper presented at the International Workshop "Human Security and Climate Change" in Asker, Norway.

[36] STEWARD, S.I. (2002). Amenity migration. In: K. Luft, S. MacDonald (eds.): Shaping the Future (pp. 369-378). In 5th Outdoor Recreation \& Tourism Trends Symposium. Lansing: Michigan State University.

[37] TĚŠITEL, J., KUŠOVÁ, D. \& BARTOŠ, M. (2001). Population size - the indicator of the response of local population to external pressure (a case study of the right shore of the Lipno lake area). Ekológia (Bratislava) 20(1), 29-37.

[38] TĚŠITEL, J., KUŠOVÁ, D. \& BARTOŠ, M. (2003): Tourist's reasons for visiting mountain areas: a case study of the Šumava Mountains. Landscape Research 28(3), 317-322. 
[39] TĚŠITEL, J., KUŠOVÁ, D. \& BARTOŠ, M. (1999). Non marginal parameters of marginal areas. Ekológia (Bratislava) 18(2), 39-46. 